\title{
MEDIA PERMAINAN ULAR TANGGA, MOTIVASI DAN HASIL BELAJAR PESERTA DIDIK DI SEKOLAH DASAR
}

\author{
Elke Maisyarah ${ }^{1)}$,Firman Firman ${ }^{2)}$ \\ Jurusan Program Studi Pendidikan Dasar dan Jurusan Bimbingan dan \\ Konseling Fakultas IImu Pendidikan Universitas Negeri Padang \\ E-mail : firman@konselor.org
}

\begin{abstract}
ABSTRAK
Artikel ini bertujuan untuk membahas secara konseptual tentang penggunaan media permainan ular tangga terhadap motivasi dan hasil belajar peserta didik. Dimana peserta didik diharapkan mampu memiliki motivasi yang tinggi dalam mengikuti proses pembelajaran dengan menggunakan media permainan ular tangga. Pada saat ini, motivasi peserta didik cenderung rendah. Ini disebabkan karena kurangnya ketertarikan peserta didik terhadap media yang digunakan oleh guru dalam proses pembelajaran. Hal ini tentu menjadi penyebab hasil belajar peserta didik tidak sesuai dengan tujuan yang ingin dicapai. Oleh sebab itu, perlu adanya penggunaan media yang sesuai dengan karakteristik peserta didik dalam proses pembelajaran untuk meningkatkan motivasi dan hasil belajar peserta didik.
\end{abstract}

Kata kunci: media pembelajaran, permainan ular tangga, motivasi, hasil belajar.

\section{PENDAHULUAN}

Pendidikan memegang peranan penting sebagai wahana untuk mempersiapkan peserta didik menghadapi dunianya dimasa depan. Seorang guru harus sanggup menciptakan suasana belajar yang nyaman serta mampu memahami sifat peserta didik yang berbeda dengan peserta didik yang lain. Guru juga bertanggung jawab atas segala sikap dan tingkah laku dan perbuatannya dalam rangka membina jiwa dan watak peserta didik.
Tujuan dari pembelajaran tersebut diperlukan untuk meningkatkan sumber daya manusia yang baik agar mampu menghadapi perkembangan dalam berbagai aspek kehidupan. Pendidikan yang dimaksud adalah pendidikan yang mencakup ranah kognitif, afektif dan psikomotorik. Luasnya cakupan dalam pendidikan memerlukan banyak unsur yang saling bersinergi untuk mencapai tujuan pendidikan.

Untuk mencapai tujuan tersebut, semuanya tidak lepas dari proses pembelajaran yang merupakan unsur 
penting dalam pendidikan tersebut. Dengan demikian, belajar yang berhasil mesti melalui berbagai macam aktivitas, baik aktivitas fisik maupun psikis. Seluruh peranan dan kemauan diarahkan supaya peserta didik tetap aktif untuk mendapatkan hasil pengajaran yang optimal sekaligus mengikuti proses pengajaran secara aktif. Disamping itu guru harus sedapat mungkin memotivasi peserta didik dengan berbagai cara diantaranya memperkenalkan kepada peserta didik bermain sambil belajar. Salah satu mata pelajaran yang bisa dilakukan oleh peserta didik sambil bermain adalah pelajaran matematika. Belajar matematika sambil bermain dapat menumbuhkan motivasi belajar peserta didik dalam upaya meningkatkan keterampilan, penanaman konsep, pemahaman, pemantapan, dan juga meningkatkan kemampuan menemukan, serta memecahkan masalah.

Motivasi yang diberikan kepada peserta didik diharapkan mampu meningkatkan hasil belajar peserta didik sesuai dengan tujuan yang ingin dicapai dalam pembelajaran itu sendiri. Selain itu motivasi juga dapat berperan dalam penguatan belajar dalam menyelesaikan tugas apabila peserta didik menyelesaikan tugas dihadapkan pada suatu masalah yang memerlukan pemecahan dan hanya dapat dipecahkan berkat bantuan hal-hal yang pernah dilaluinya. Penguatan belajar dalam menyelesaikan tugas melalui motivasi dapat membantu peserta didik untuk mampu memiliki hasil belajar sesuai dengan yang ingin dicapai (Desyafmi, Firman, \& Ifdil, 2016) .

Motivasi yang diberikan guru, dapat melalui proses pembelajaran dengan menggunakan permainan ular tangga. Ini dikarenakan, karakter usia peserta didik masih dalam tingkatan cenderung bermain. Dimana permainan ini sesuai dengan perkembangan kognitif peserta didik yang berkisar antara usia 8 sampai 11 tahun. Pada permainan ini, peserta didik mulai dapat menerima suatu permaianan yang banyak diwarnai dengan nalar dan logika yang bersifat obyektif serta kegiatan peserta didik lebih banyak dikendalikan oleh aturan yang ada didalam permainan 
itu sendiri. Begitupun dengan permainan ular tangga , peserta didik juga dikendalikan oleh aturan aturan yang ada. (Siyam, Syarifah Nur LailiSiyam, S. N. L., Nurhapsari, A., \& Benyamin, B. (2015).

Permainan sebagai suatu media pembelajaran memiliki beberapa kelebihan, diantaranya permainan adalah sesuatu yang untuk dilakukan, sesuatu yang menghibur. Permainan memungkinkan adanya partisipasi aktif dari peserta didik untuk belajar. Permainan memberikan pengalamanpengalaman nyata yang memancing peserta didik untuk lebih mampu aktif dan terampil dalam pembelajaran. Selain itu, dengan bermain peserta didik tidak akan merasa bosan dalam proses pembelajaran sehingga materi yang diajarkan oleh guru dalam proses pembelajaran mampu diterima dengan baik oleh peserta didik. Sehingga dengan adanya permanan ular tangga sebagai penunjang proses pembelajaran bagi peserta didik diharapkan peserta didik mampu memperoleh hasil belajar sesuai dengan tujuan yang telah dirancang oleh guru sebelum proses pembelajaran berlangsung. (Siyam, Syarifah Nur LailiSiyam, S. N. L., Nurhapsari, A., \& Benyamin, B. 2015).

Berdasarkan alasan-alasan di atas, penulis akan melakukan pengamatan untuk perbaikan pembelajaran yang dirancang melalui 1: "Penggunaan Media Permainan Ular Tangga Pada Mata Pelajaran Matematika Materi Bangun Datar Terhadap Motivasi dan Hasil Belajar Peserta Didik Sekolah Dasar"

\section{MEDIA}

Secara umum, media dalam proses pembelajaran adalah untuk memperlancar interaksi antara guru dan murid sehingga kegiatan pembelajaran akan lebih efektif dan efisien. Proses pembelajaran yang menggunakan media dapat memperagakan fakta, konsep, prinsip agar tampak lebih nyata. Di dalam pengajaran dikenal beberapa istilah seperti peragaan. Tetapi dewasa ini istilah peragaan telah mulai dipopulerkan dengan istilah media. 
Media dalam proses pembelajaran adalah segala sesuatu yang dapat dipergunakan untuk menyalurkan pesan, membangkitkan keinginan dan minat yang baru, membangkitakan motivasi dan rangsangan pembelajaran dan bahkan membawa pengaruh psikologi terhadap siswa. Pesan yang disalurkan melalui media ini diharapkan mampu untuk membangkitkan motivasi peserta didik dalam proses pembelajaran sehingga hasil belajar peserta didik mampu meningkat sesuai dengan tujuan yang ingin dicapai dalam proses pembelajaran. (Taufina , J., Pendidikan, I., \& Xii, V. (2012)

Seorang guru dalam menyajikan materi pembelajaran hendaknya jeli dalam menentukan media pembelajaran yang akan digunakan, sebab media pembelajaran dalam beberapa macam yang penggunaanya disesuaikan dengan materi pembelajaran dan berkarakteristik peserta didik, pemilihan dan penggunaan media yang tepat tentunya akan memaksimalkan hasil belajar peseta didik dan sesuai dengan yang diharapkan. Sehingga didalam proses pembelajaran peserta didik memiliki motivasi yang tinggi untuk dapat mengikuti proses pembelajaran dengan baik (Ilmiah, Pendidikan, \& Xii, 2012)

\section{MEDIA PERMAINAN ULAR}

\section{TANGGA}

Permainan ular tangga adalah permainan papan yang dimainkan oleh dua orang atau lebih. Permainan ular tangga diharapkan dapat meningkatkan minat siswa karena Permainan ini mudah dilakukan, sederhana peraturannya dan mendidik apabila diberikan tema yang positif. Selain itu permainan ular tangga membuat siswa menjadi lebih aktif karena siswa dapat berpartisipasi langsung dalam pembelajaran.

Alat permainan edukatif adalah segala sesuatu yang dapat digunakan sebagai sarana atau peralatan untuk bermain yang mengandung nilai edukatif (pendidikan) dan dapat mengembangkan seluruh kemampuan anak (Departemen Pendidikan Nasional, 2007: 5). APE dapat dapat digunakan sebagai media 
belajar sambil bermain. Alat Permainan Edukatif yang akan dikembangkan yaitu ular tangga matematika pada materi luas bangun ruang untuk peserta didik Sekolah Dasar . Alat Permainan Edukatif ular tangga matematika ini merupakan pengembangan dari media permainan ular tangga yang dimodifikasi dengan menambah soal-soal pada kotak tertentu yang harus dijawab. Permainan ular dipilih karena permainan ini biasa dimainkan anakanak. Selain itu ular tangga mudah dimainkan dan memiliki daya tarik tinggi terutama bagi anak usia sekolah dasar. Kelebihan APE ular tangga matematika yang akan dikembangkan adalah bukan sekedar permainan ular tangga biasa, melainkan sebuah permainan yang dilengkapi materi luas bangun datar dan soal-soal yang dikemas di dalam bentuk permainan. Melalui APE ular tangga matematika ini diharapkan dapat meningkatkan minat siswa belajar matematika. Melihat asumsi yang telah dipaparkan di atas yang menjadi latar belakang pentingnya penelitian ini dilakukan. (Siyam, Syarifah Nur LailiSiyam, S. N. L.,
Nurhapsari, A., \& Benyamin, B. (2015). Pengaruh Stimulasi Permainan Ular Tangga Tentang Gingivitis Terhadap Pengetahuan Anak Usia 8-11 Tahun. ODONTO Dental Journal, 2 (1), 2015)

\section{MOTIVASI}

Pada dasarnya motivasi adalah suatu usaha yang disadari untuk menggerakkan, menggarahkan dan menjaga tingkah laku seseorang agar ia terdorong untuk bertindak melakukan sesuatu sehingga mencapai hasil atau tujuan tertentu. Menurut Clayton Alderfer (dalam Nashar, 2004:42) Motivasi belajar adalah kecenderungan siswa dalam melakukan kegiatan belajar yang didorong oleh hasrat untuk mencapai prestasi atau hasil belajar sebaik mungkin.(Hamdu \& Agustina, 2011)

Motivasi dipandang sebagai dorongan mental yang menggerakkan dan mengarahkan perilaku manusia, termasuk perilaku belajar. Dalam motivasi terkandung adanya keinginan yang mengaktifkan, menggerakkan, menyalurkan dan mengarahkan sikap serta perilaku pada individu belajar 
yang dapat dilakukan adalah mengidentifikasi beberapa indikatornya dalam tahap-tahap tertentu. Indikator motivasi antara lain: 1) Durasi kegiatan, 2) Frekuensi kegiatan, 3) Presistensinya pada tujuan kegiatan,4) Ketabahan, keuletan dan kemampuannya dalam menghadapi kegiatan dan kesulitan untuk mencapai tujuan, 5) Pengabdian dan pengorbanan untuk mencapai tujuan, 6) Tingkatan aspirasi yang hendak dicapai dengan kegiatan yang dilakukan, 7) Tingkatkualifikasi prestasi, 8) Arah sikapnya terhadap sasaran kegiatan (Hamdu \& Agustina, 2011)

\section{HASIL BELAJAR}

Hasil belajar adalah kemampuan yang dimiliki peserta didik setelah ia menerima pengalaman belajar . Hasil belajar peserta didik pada hakikatnya adalah perubahan mencakup bidang kognitif, afektif dan psikomotoris berorientasi pada proses belajar mengajar yang dialami peserta didik.

Hasil belajar dalam hal ini berhubungan dengan tujuan instruksional dan pengalaman belajar. Adanya tujuan instruksional merupakan panduan tertulis akan perubahan perilaku yang diinginkan pada diri peserta didik, sementara pengalaman belajar meliputi apa-apa yang dialami peserta didik baik itu kegiatan mengobservas membaca, meniru,mencoba sesuatu sendiri, mendengar, mengikuti perintah . Sistem pendidikan nasional dan rumusan tujuan pendidikan; baik tujuan kurikuler maupun tujuan instruksional pada umumnya menggunakan klasifikasi hasil belajar Bloom yang secara garis besar membaginya menjadi tiga ranah, ranah kognitif, afektif, dan psikomotoris. Ranah kognitif berkenaan dengan hasil belajar intelektual yang terdiri dari enam aspek, yakni: knowledge (pengetahuan), comprehension (pemahaman), aplikasi, analisis, sintesis, dan evaluasi. Kedua aspek pertama disebut kognitif tingkat rendah dan keempat aspek berikutnya termasuk kognitif tingkat tinggi. Ranah afektif berkenaan dengan sikap yang terdiri dari lima aspek, yakni: penerimaan, jawaban atau reaksi, penilaian, organisasi, dan internalisasi. Ranah psikomotoris 
berkenaan dengan hasil belajar keterampilan dan kemampuan bertindak yang terdiri atas enam aspek, yakni: gerakan refleks, keterampilan dasar, kemampuan perseptual, keharmonisan atau ketepatan, gerakan keterampilan kompleks, dan gerakan ekspresif dan interpretatif (Ramadhani, 2012).

Pada dasarnya hasil belajar terbagi kedalam tiga ranah, yakni ranah kognitif, ranah afektif dan ranah psikomotoris. (Ramadhani, 2012) yaitu :

1) Ranah kognitif

Ranah ini berkenaan dengan hasil belajar intelektual yang terdiri dari enam aspek, yakni pengetahuan (knowledge), pemahaman, aplikasi,analisis, sintesis dan evaluasi.

2) Ranah afekif

Ranah afektif berkenaan dengan sikap dan nilai. Tipe hasil belajar afektif tampak pada siswa dalam berbagai tingkah laku seperti perhatiaannya terhadap pelajaran, disiplin, motivasi belajar, menghargai guru, kebiasaan belajar, dan hubungan sosial.
3) Ranah psikomotoris

Hasil belajar psikomotoris tampak dalam bentuk keterampilan (skill) dan kemampuan bertindak individu.

\section{KESIMPULAN}

Penggunaan media permainan ular tangga dapat meningkatkan dan menumbuhkan motivasi dan hasil belajar peserta didik. Oleh sebab itu, dengan menggunakan media permainan ular tangga dalam proses pembelajaran Sekolah Dasar dapat meningkatkan dan menumbuhkan motivasi peserta didik sehingga hasil belajar peserta didikpun meningkat. Diharapkan dengan adanya penggunaan media peserta didik lebih mampu untuk mencapi tujuan pembelajaran.

\section{DAFTAR PUSTAKA}

Dan Tabel Krejcie-Morgan, S., Konsep Dan Aplikasinya Oleh, T., \& Setiawan Fakultas Peternakan Universitas Padjadjaran, N. (2007). Penentuan Ukuran Sampel Memakai Rumus, (November).

Desyafmi, H., Firman, F., \& Ifdil, I. (2016). Peningkatan Motivasi Siswa Dalam Menyelesaikan Tugas Melalui Layanan Informasi. Konselor, 3(1), 3541. 
Hamdu, G., \& Agustina, L. (2011). Pengaruh Motivasi Belajar Siswa Terhadap Prestasi Belajar Ipa Di Sekolah Dasar. Penelitian Pendidikan, 12(1), 90-96.

Ilmiah, J., Pendidikan, I., \& Xii, V. (2012). Peningkatan Keterampilan Berbicara Dengan Menggunakan Media Film Strip Di Kelas Ii Sd Percobaan Kota Padang Oleh: Taufina Taufik Universitas Negeri Padang, Xii(1).

Ramadhani, M. (2012). Efektivitas Penggunaan Media Pembelajaran E-Learning Berbasis Web Pada Pelajaran Teknologi Informasi Dan Komunikasi Terhadap Hasil Belajar Siswa Kelas X Sma Negeri 1 Kalasan, 1-30.

Siyam, Syarifah Nur Lailisiyam, S. N. L., Nurhapsari, A., \& Benyamin, B. (2015). Pengaruh Stimulasi Permainan Ular Tangga Tentang Gingivitis Terhadap Pengetahuan Anak Usia 8-11 Tahun. Odonto Dental Journal, 2 (1), 25-28. (2015). Pengaruh Stimulasi Permainan Ular Tangga Tentang Gingivitis Terhadap Pengetahuan Anak Usia 8-11 Tahun.

(Ilmiah Et Al., 2012)Dan Tabel Krejcie-Morgan, S., Konsep Dan Aplikasinya Oleh, T., \& Setiawan Fakultas Peternakan Universitas Padjadjaran, N. (2007). Penentuan Ukuran
Sampel Memakai Rumus, (November).

Desyafmi, H., Firman, F., \& Ifdil, I. (2016). Peningkatan Motivasi Siswa Dalam Menyelesaikan Tugas Melalui Layanan Informasi.

Hamdu, G., \& Agustina, L. (2011). Pengaruh Motivasi Belajar Siswa Terhadap Prestasi Belajar Ipa Di Sekolah Dasar. Penelitian Pendidikan, 12(1), 90-96.

Ilmiah, J., Pendidikan, I., \& Xii, V. (2012).

Peningkatan Keterampilan Berbicara Dengan Menggunakan Media Film Strip Di Kelas Ii Sd Percobaan Kota Padang Oleh: Taufina Taufik Universitas Negeri Padang, Xii(1).

Ramadhani, M. (2012). Efektivitas Penggunaan Media

Pembelajaran E-Learning Berbasis Web Pada Pelajaran Teknologi Informasi Dan Komunikasi Terhadap Hasil Belajar Siswa Kelas X Sma Negeri 1 Kalasan, 1-30.

Siyam, Syarifah Nur Lailisiyam, S. N. L., Nurhapsari, A., \& Benyamin, B. (2015). Pengaruh Stimulasi Permainan Ular Tangga Tentang Gingivitis Terhadap Pengetahuan Anak Usia 8-11 Tahun. Odonto Dental Journal, 2 (1), 25-28. (2015). Pengaruh Stimulasi Permainan Ular Tangga Tentang Gingivitis Terhadap Pengetahuan Anak Usia 8-11 
Tahun.

Desyafmi, H., Firman, F., \& Ifdil, I. (2016). Peningkatan Motivasi Siswa Dalam Menyelesaikan Tugas Melalui Layanan Informasi. Konselor, 3(1), 3541.

Hamdu, G., \& Agustina, L. (2011). Pengaruh Motivasi Belajar Siswa Terhadap Prestasi Belajar Ipa Di Sekolah Dasar. Penelitian Pendidikan, 12(1), 90-96.

Ilmiah, J., Pendidikan, I., \& Xii, V. (2012). Peningkatan Keterampilan Berbicara Dengan Menggunakan Media Film Strip Di Kelas Ii Sd Percobaan Kota Padang Oleh: Taufina Taufik Universitas Negeri Padang, Xii(1).

Ramadhani, M. (2012). Efektivitas Penggunaan Media Pembelajaran E-Learning Berbasis Web Pada Pelajaran Teknologi Informasi Dan Komunikasi Terhadap Hasil Belajar Siswa Kelas X Sma Negeri 1 Kalasan, 1-30.

Siyam, Syarifah Nur Lailisiyam, S. N. L., Nurhapsari, A., \& Benyamin, B. (2015). Pengaruh Stimulasi Permainan Ular Tangga Tentang Gingivitis Terhadap Pengetahuan Anak Usia 8-11 Tahun. Odonto Dental Journal, 2 (1), 25-28. (2015). Pengaruh Stimulasi Permainan Ular Tangga Tentang Gingivitis Terhadap Pengetahuan Anak Usia 8-11
Tahun.

Dan Tabel Krejcie-Morgan, S., Konsep Dan Aplikasinya Oleh, T., \& Setiawan Fakultas Peternakan Universitas Padjadjaran, N. (2007). Penentuan Ukuran Sampel Memakai Rumus, (November).

Desyafmi, H., Firman, F., \& Ifdil, I. (2016). Peningkatan Motivasi Siswa Dalam Menyelesaikan Tugas Melalui Layanan Informasi. Konselor, 3(1), 3541.

Hamdu, G., \& Agustina, L. (2011). Pengaruh Motivasi Belajar Siswa Terhadap Prestasi Belajar Ipa Di Sekolah Dasar. Penelitian Pendidikan, 12(1), 90-96.

Ramadhani, M. (2012). Efektivitas Penggunaan Media Pembelajaran E-Learning Berbasis Web Pada Pelajaran Teknologi Informasi Dan Komunikasi Terhadap Hasil Belajar Siswa Kelas X Sma Negeri 1 Kalasan, 1-30.

Siyam, Syarifah Nur Lailisiyam, S. N. L., Nurhapsari, A., \& Benyamin, B. (2015). Pengaruh Stimulasi Permainan Ular Tangga Tentang Gingivitis Terhadap Pengetahuan Anak Usia 8-11 Tahun. Odonto Dental Journal, 2 (1), 25-28. (2015). Pengaruh Stimulasi Permainan Ular Tangga Tentang Gingivitis Terhadap Pengetahuan Anak Usia 8-11 
Tahun.

Dan Tabel Krejcie-Morgan, S., Konsep Dan Aplikasinya Oleh, T., \& Setiawan Fakultas Peternakan Universitas Padjadjaran, N. (2007). Penentuan Ukuran Sampel Memakai Rumus, (November).

Desyafmi, H., Firman, F., \& Ifdil, I. (2016). Peningkatan Motivasi Siswa Dalam Menyelesaikan Tugas Melalui Layanan Informasi. Konselor, 3(1), 3541.

Hamdu, G., \& Agustina, L. (2011)

- Pengaruh Motivasi Belajar Siswa Terhadap Prestasi Belajar Ipa Di Sekolah Dasar. Penelitian Pendidikan, 12(1), 90-96.

Ilmiah, J., Pendidikan, I., \& Xii, V. (2012).

Peningkatan

Keterampilan Berbicara Dengan Menggunakan Media Film Strip
Di Kelas Ii Sd Percobaan Kota Padang Oleh: Taufina Taufik Universitas Negeri Padang, Xii(1).

Ramadhani, M. (2012). Efektivitas Penggunaan Media Pembelajaran E-Learning Berbasis Web Pada Pelajaran Teknologi Informasi Dan Komunikasi Terhadap Hasil Belajar Siswa Kelas X Sma Negeri 1 Kalasan, 1-30.

Siyam, Syarifah Nur Lailisiyam, S. N. L., Nurhapsari, A., \& Benyamin, B. (2015). Pengaruh Stimulasi Permainan Ular Tangga Tentang Gingivitis Terhadap Pengetahuan Anak Usia 8-11 Tahun. Odonto Dental Journal, 2 (1), 25-28. (2015). Pengaruh Stimulasi Permainan Ular Tangga Tentang Gingivitis Terhadap Pengetahuan Anak Usia 8-11 . 